\title{
Din Kültürü ve Ahlak Bilgisi Öğretmen Adaylarının Benimsedikleri Eğitim Felsefeleri
}

\section{Educational Philosophies Adopted by Pre-service Teachers of Religion}

\author{
Mehmet Kamil Coşkun a,* \\ a Doç. Dr., Muș Alparslan Üniversitesi, İslami İlimler Fakültesi, 49250, Muş/Türkiye. \\ ORCID: 0000-0002-5669-2777
}

\section{MAKALE BILGİSI}

Makale Geçmişi:

Başvuru tarihi: 25 Nisan 2018

Düzeltme tarihi: 25 Mayıs 2018

Kabul tarihi: 09 Haziran 2018

Anahtar Kelimeler:

Eğitim Felsefesi

Din Kültürü ve Ahlak Bilgisi

Öğretmen Adayları

\section{ARTICLE INFO}

Article history:

Received 25 April 2018

Received in revised form 25 May 2018

Accepted 09 June 2018

\section{Keywords:}

Educational Philosophy

Religion Teacher

Religion Lesson
ÖZ

Araştırmada, din kültürü ve ahlak bilgisi (DKAB) öğretmen adaylarının benimsedikleri eğitim felsefeleri belirlenmiş; bölüm, cinsiyet, sınıf düzeyi gibi çeşitli değişkenlerin etkisi ortaya çıkarılmıştır. Araştırmanın örneklemini çeşitli üniversitelerin İlahiyat ve DKAB Eğitimi programlarında öğrenim gören 288 öğrenci oluşturmaktadır. Tarama modelinde betimsel olarak yürütülen araştırmada; Çetin, İlhan ve Arslan tarafından geliştirilen "Felsefi Tercih Değerlendirme Ölçeği” kullanılmıştır. Araştırmaya katılan DKAB öğretmen adaylarının daimici - esasici eğitim felsefelerini, ilerlemeci - yeniden kurmacı eğitim felsefelerine göre daha çok benimsedikleri görülmüştür. Araştırmada, cinsiyetin ve öğrenim görülen lisans programının öğretmen adaylarının benimsedikleri eğitim felsefeleri üzerinde etkili bir değişken olmadığı; buna karşın sınıf düzeyi değişkeninin öğretmen adaylarının benimsedikleri eğitim felsefelerini anlamlı şekilde farklılaştırdığı tespit edilmiştir.

\section{A B S T R A C T}

The aim of this research is to examine the educational philosophies adopted by pre-service teachers of religious culture and ethics in terms of different variables. The sampling of the research consisted of 288 students studying in the Department of Divinity and in the Department of Religious Education. As data collection tools, "Philosophy Preference Assessment Scale" which had been developed by Çetin, İlhan and Arslan was used. It was understood that the pre-service teachers of religion were more likely to adopt traditional philosophies of education, which are based on perennialism and essentialism. The variables gender and department did not have a significant effect on the results, whereas the variable grade had a significant effect on the extent to which they adopted traditional or contemporary philosophies of education.

\section{Giriş}

Eğitim felsefelerinin; eğitime dair teori ve pratikleri bütüncül bir bakışla ele alma, eğitimi engelleyen sorunları, eğitime yön veren kavram, düşünce ve ilkeleri açıklama, eğitim politikalarına ve uygulamalarına istikamet verme gibi bir rolü vardır. Eğitim felsefesinde, özellikle 20. yüzyılda çok bariz olarak ortaya çıkan üç temel yönelim veya eğilim bulunmaktadır. $\mathrm{Bu}$ eğilimlerden birincisi normatif / preskriptif yönelimdir. Preskriptif eğitim felsefeleri; eğitimin ne olmas1, öğretim faaliyetlerinin nasıl düzenlenmesi gerektiğiyle ilgili bir eğitim anlayışı ya da kuramını savunurlar. Eğilimlerden ikincisi olan analitik eğitim felsefeleri insanlara eğitimle ilgili tercihlerinin ne şekilde olması gerektiğiyle ilgili telkinlerde bunmanın doğru ve etik olmadığını öne sürer. Bunun yerine eğitimle ilgili temel kavramları izah etmeyi, insanların eğitim konusunda birtakım tercihler yaparken veya kararlar alırken; esas aldıkları ilkeleri, benimsedikleri anlayışları aydınlatmayı hedefler. Eğitim felsefesinde bir diğer temel yönelim, kritik ya da eleştirel eğitimdir. Bu yönelim de büyük ölçüde analitik yönelime bezer şekilde zemini temizlemeye, manipülatif algıları ve hatalı izlenimleri açığa çıkarmaya, ideolojilerin empoze ettiği anlayışları ortadan kaldırmaya çalışır. Eğitimle ilgili tüm yanlış anlayışların, toplumda zayıf grupların ihtiyaçlarıyla ve gerçek çıkarlarıyla çeliştiğini düşünen eleştirel eğilim, bu yüzden öncelikle hatalı algıları

*Sorumlu yazar/Corresponding author.

e-posta: mk.coskun@alparslan.edu.tr 
ve yanlıș kavrayışları düzeltmeyi, ideolojilerin maskelerini düşürmeyi amaç edinir(Cevizci, 2016: 17).

\subsection{Normatif / Preskriptif Eğitim Felsefeleri}

Literatürde normatif / preskriptif anlamda eğitime yön veren felsefi akımlar genellikle; daimicilik, esasicilik, ilerlemecilik, yeniden kurmacılık, doğacılık ve varoluşçuluk olarak ele alınmaktadır. Normatif / prekriptif yönelime dayanan bu felsefelerin bir k1smı, genel felsefelerden hareketle ortaya çıkmıştır. Örneğin daimicilik ve esasicilik, kaynağını idealizm ve realizmden; ilerlemecilik ve doğacılık ise, pragmatizmden almaktadır (Çetin, İlhan ve Arslan, 2012).

Daimicilik temelde idealizme dayanmaktadır. Daimiciler, eğitimde evrensel ilkelere ve geleneğe vurgu yaparlar. $\mathrm{Bu}$ akıma göre eğitim, değişmez olana uyum sağlamaya yardım etmelidir. Çünkü hayatın, toplumun ve insanın değişmeyen bazı gerçekleri vardır ve eğitim de kendisini bu gerçekler üzerine kurmalıdır. Bu bağlamda, eğitimin en temel amacı kalıcı değer ve fikirlerin aktarılmasıdır. (Arslan, 1998; Cevizci, 2016; Sönmez, 2011). İdealizm akımı, çok eski çağlardan bu yana var olan felsefi bir akımdır. Bütün varlıkların, dünyanın, duyularımızın algıladığından farklı bir şey olduğunu, nesnelerin ancak bizim varlığımızla var olduğunu ve gerçek bilginin aklın ürünü olduğunu iddia eder (Ergün, 1996: 75). İdealizme göre doğru, mutlak, kesin nitelik taşıyan bilgiler aprioridir; yani insan aklında önceden vardır. İnsan, doğru bilgiye aklını kullanarak ulaşabilir. Bunun için insanın kendi içine dönüp tümdengelim yöntemi ve onun kurallarıyla hareket etmelidir; çünkü insanın kendi aklı, değişmez büyük aklı haizdir. Akıl, kendisini müşahede ederek, etrafındaki suni yapılardan hareketle değişmez, ölümsüz, aslını kaybetmeyen ve bir olan gerçekle ilgili mutlak, kesin doğruya nail olur. Bunun için kişi murakabe içinde olmalıdır. (Sönmez, 2011: 74). İdealist eğitim anlayışına göre insanın değiş̧mez gerçeklere veya hakikatin bilgisine ulaşabilmesi için öncelikle akıl ile hakikat arasında perde olan maddi unsurların bertaraf edilmesi, dolayısıyla ruhun gözünün açılması gerekmektedir (Cevizci, 2016). Öğrencinin ilgi ve isteğiyle, öğrenme gücü arasında anlamlı bir ilişki olduğundan, idealizme göre okul ve öğrenme öğretme ortamı, öğrencinin ilgilerini uyaracak biçimde tasarlanmalıdır. Zira öğrencideki bu deruni istek, onu belli olgu, olay ve nesnelere yönlendirir. Zaten bu yöneliş sağlandıktan sonra, öğrenme için başka hiçbir uyarıcıya, bilinçli çabaya da gerek yoktur (Sönmez, 2011: 74). Öğrencinin entelektüel gayretinin maddi ve hissi olandan uzaklaştırılıp onda bir dönüşüm sağlanmasını ve sonunda hakikatin bilgisine ulaşmasını amaçlayan idealist eğitim anlayışı, Sokratik tartışma yönteminin hakim olduğu öğrenme ortamında, öğretmeni merkezliliği savunmaktadır (Cevizci, 2016: 30).

Esasicilik temelde realizme dayanmaktadır. Esasiciler, bireyin toplumsallaşmasına vurgu yaparlar, insanın değişmez bir özünün var olduğunu ve öğrencilere olgun bir hayat yaşamaları açısından ihtiyaç duydukları temel bilgileri kazandıracak birtakım değişmez bilgi ve değerlerin bulunduğunu öne sürerler. Bu felsefi akıma göre eğitime düşen şeyin insanı akademik bilgi ve karakter gelişiminin temel unsurlarıyla donatmak, okulun en başat misyonu da insanlık kültürünün temel unsurlarını aktarıp korumaktır.
Böylece müfredatın konu ve öğretmen merkezli olması gerektiği noktasında daimicilikle örtüşen esasicilik, okulun en önemli görevini, gençlere belli başlı ilmi disiplinleri öğretmek, önemli genel becerileri kazandırmak ve böylelikle de kültürel mirasın devamlılığını sağlamak olduğunu iddia eder (Cevizci, 2016). Bu itibarla esasiciliğin, konu ve disiplin merkezli bir eğitim felsefesi olduğu söylenebilir.

İlerlemecilik temelde pragmatizme dayanmaktadır. Eğitimin en önemli amacının sonraki deneyimlerin yönlendirilmesini mümkün kılacak şekilde gelişme olduğunu ileri süren pragmatist eğitim anlayışı, bu bağlamda geleneksel okulun hazırlanma öğretisine yaptığı vurguya karşı çıkar. Hayatı değişen bir dünya ve toplum içinde yaşanan bir süreç olarak değerlendiren pragmatizm, eylemi okul sonrasına ertelemenin öğrencileri hazırlanmış oldukları dünyadan farklı bir dünyaya hazırlama olduğunu ileri sürer. Bu yüzden o, uzak bir geleceği beklemek yerine, öğrencilerin mevcut problemleri çözmelerinin temin edecek ilgi ve ihtiyaçlara göre hareket etmelerinin sağlanması gerektiğini savunur. Pragmatizm onların, gündelik deneyimlerinden de yararlanmak suretiyle şimdiye olduğu kadar geleceğe de uygulanabilir olan bir problem çözme yöntemini içselleştirmelerini ve böylelikle gerçekleşecek olan gelişmeyi eğitimin en temel amacı yapar (Dewey, 1996: 6870). Pragmatizmin eğitim teorisine tekabül eden ilerlemecilik, eğitimsel amaçları arasında en baş sırayı, bireylerin gelişmesini temin etmeye, onlara kendi bilgi kavrayışlarını yapılandırma veya inşa etme imkânı sağlanmasına verir (Kop, 2004: 271). Bu inşa ve yaratma süreci ise çok büyük ölçüde bireylerin bildikleri ve inandıkları şeylerin yeni karşılaştıkları olay, etkinlik ve fikirlerle karşılıklı bir ilişkiye sokulmasında meydana gelir. $\mathrm{Bu}$ yüzden onun eğitim pratiğinde, öğrencilerin anlamı inşa etmelerini mümkün kılacak etkenlikler, onların mevcut bilgilerine yeni bilgiler katmalarını temin edecek bir müfredat programı, işbirliği içinde karşılıklı öğrenme anlayışı, projelere dayalı değerlendirme teknikleri çok önemli bir yer tutar (Cevizci, 2016: 130-131).

Yeniden kurmacı eğitim felsefesine göre toplumun değişimi ve dönüşümü politikayla değil, eğitimle mümkün olacaktır. $\mathrm{Bu}$ akıma göre, yok olma veya yeniden var olma aşamasına gelen insanlığın kendisini koruyabilmesi ve yeniden daha tutarlı bir uygarlığa geçmesi; çatışan değerlerden kurtulmasıyla mümkün olacaktır. Bu da ancak sevgi, işbirliği ve hayatı her zaman yeniden kurmakla mümkündür. Sürekli değişim, hayatın kuralı olduğundan insanlık onu daima yeniden inşa etmek zorundadır; çünkü bunu ihmal ederse mutlu olamayacak, dünya uygarlığını ve barışını kuramayacaktır. Bu amaca ulaştıracak en güçlü araç şüphesiz ki eğitimdir. Bundan dolayı eğitimin görevi; toplumun bu yöndeki hedeflerini tespit etme, uygulama, meşru kılma ve tutarlı değerlerle beslemedir. Bu bağlamda eğitimin hedefleri; dünya uygarlığını kurma, barışı ve insanların mutluluğunu sağlama, uygulama yoluyla değişmeyi gerçekleştirme; sevgi, işbirliği, denge gibi değerleri kazandırma, bu tür tutarlı kültürel değerlerin sürekliliğini sağlama, bilimsel yöntemi ve eleştirel düşünceyi kullanma, demokratik yaşam biçimini işe koşma, yaşamı sürekli yeniden kurma, bir sonraki hareketi planlama, akıllıca eylemde bulunma, hiçbir bilgiyi mutlak kabul etmeme, kişinin gizil yeteneklerini ve zihnini geliştirme vb. olabilir. Yeniden kurmacılıkta eğitimin görevi; toplumu 
sürekli yeniden şekillendirmek ve düzenlemektir. Bunun için okul, açık seçik bir şekilde toplumu değiştirme ve yeniden kurmayı sağlayacak öğretim programları geliştirmeli ve uygulamaya koymalıdır. Kişiler; hem bu ıslahı gerçekleştirecek, hem de denetleyecek biçimde yetiştirilmelidir. $\mathrm{Bu}$ iş her kişinin düşüncelerini değiştirmekle sağlanabilir; çünkü kişinin düşüncelerini değiştirmeden toplumun sslahı ve onun yeniden kurulması gerçekleşemez (Sönmez, 2011: 103-105).

\subsection{Araştırmanın Amacı}

Felsefi kabullerden hareketle gelişen eğitim felsefelerinin kendine has eğitim hedefleri, öğrenci - öğretmen ilişki karakteri, içerik ve uygulama süreci, eğitim durumları ve ölçme - değerlendirme anlayışları bulunur. Öğretmenlerin eğitim anlayışları; benimsedikleri stratejiler ve eğitsel tutumlar; derslere, konulara ve öğrenci durumlarına göre değișebilmektedir (Duman, 2008). Öğretmenlerin, öğretim programıla uyumlu ve etkili öğretim tasarımları yapabilmeleri ve öğrencilerine doğru rehberlik edebilmeleri açısından öğretmenlerin veya öğretmen adaylarının benimsedikleri felsefi yaklaşımlar ile düşünme, karar verme ve planlama süreçleriyle ilgili araştırmaların yapılması büyük önem taşımaktadır.

$\mathrm{Bu}$ araştırmayla, din kültürü ve ahlak bilgisi (DKAB) öğretmen adaylarının benimsedikleri eğitim felsefelerinin saptanması; öğretmen adaylarının benimsedikleri eğitim felsefeleri ile öğrenim gördükleri kurum (İlahiyat-Eğitim) arasında anlamlı ilişki olup olmadığının belirlenmesi amaçlanmıştır.

\subsection{Araştırmanın Önemi ve Hipotezleri}

DKAB öğretmen adaylarının benimsedikleri eğitim felsefeleriyle bu dersi tasarlarken geçirdikleri düşünme, karar verme ve planlama arasındaki ilişkiyi ortaya çıkarmaya yönelik yapılan bu araştırma, din öğretimindeki kuram ve uygulama arasındaki sürece 1 şık tutacak niteliktedir.

Farklı öğretim programları uygulanan aynı branşın öğretmen adaylarının benimsedikleri eğitim felsefelerinde, öğrenim gördükleri kurumun türüne bağlı olarak bir farklılaşma olmakta mıdır, sorusu araştırmanın omurgası ve ana problemi niteliğindedir. Bununla beraber benimsenen eğitim felsefelerine ilişkin veriler; cinsiyet ve sınıf düzeyi gibi bağımsız değişkenlerle de ilişkilendirilmiştir.

Araştırmanın iki hipotezi vardır:

(i) DKAB Eğitimi programında öğrenim gören öğretmen adayları daha çok çağdaş (ilerlemeci yeniden kurmacı) eğitim felsefelerini; ilahiyat programında öğrenim öğretmen adayları daha çok geleneksel (daimici - esasici) eğitim felsefelerini benimsemektedir.

(ii) Sınıf düzeyi yükseldikçe öğretmen adaylarının çağdaş (ilermeci - yeniden kurmacı) eğitim felsefelerini benimseme eğilimleri artmakta; geleneksel (daimici - esasici) eğitim felsefelerini benimseme eğilimleri düşmektedir.

\section{Yöntem}

\subsection{Araştırmanın Modeli, Evreni ve Örneklemi}

Herhangi bir konuda var olan durumu olduğu gibi ortaya çıkarmayı, tavırları ve davranışları açıklamayı, karşılaştırmayı ve betimlemeyi amaçlayan araştırmalar tarama araştırmaları olarak tanımlanmaktadır. (Karasar, 2006; Gürsakal, 2001). DKAB öğretmen adaylarının benimsedikleri eğitim felsefelerinin belirlenmesine çalışıldığı bu araştırmada var olan durum yansıtılmaya çalışıldığından, araştırma genel ve ilişkisel tarama modelinde betimsel bir araştırma olarak planlanmıştır. Araştırmanın evrenini Türkiye'deki İlahiyat ve DKAB Eğitimi lisans programlarında okuyan öğrenciler; örneklemini ise 2015-2016 eğitim öğretim yılında Atatürk, Dicle, İnönü, Marmara, On Dokuz Mayıs, Uludağ ve Selçuk Üniversitelerinin İlahiyat ile DKAB Eğitimi programlarında öğrenim gören 170 'i kı, 118 'i erkek olmak üzere toplam 288 öğrenci oluşturmaktadır.

\subsection{Veri Toplama Aracı}

Araştırmada öğretmen adaylarının benimsedikleri eğitim felsefelerini belirlemek amaciyla Çetin, İlhan ve Arslan tarafından geliştirilen (2012) "Felsefi Tercih Değerlendirme Ölçeği” kullanılmıştır. Ölçekte; daimicilik, esasicilik, ilerlemecilik ve yeniden kurmacılık şeklinde eğitim felsefelerine ilişkin literatürde en fazla kabul gören sınıflandırma dikkate alınarak hazırlanan 39 madde yer almaktadır. Açımlayıcı faktör analizi (AFA) sonucunda, ilerlemecilik ve yeniden kurmacılık eğitim felsefelerini yansıtan 17 maddenin toplandığı birinci faktörün, toplam varyansın \%22.91'ini açıkladığı belirlenmiştir. Bu faktörde yer alan maddelerin faktör yükleri .34 ile .76 arasında değişmektedir. Daimicilik ve esasicilik eğitim felsefelerini yansıtan 22 maddenin toplandığı ikinci faktörün ise toplam varyansın $\% 12.77^{\text {ee }}$ sini açıkladığı tespit edilmiştir. Bu faktörde yer alan maddelerin faktör yükleri ise 0.34 ile 0.69 arasında sıralanmaktadır. Literatürde, daimicilik ve esasicilik Geleneksel Eğitim Felsefeleri (GEF); ilerlemecilik ve yeniden kurmacılık ise Çağdaş Eğitim Felsefeleri(ÇEF) olarak isimlendirilmektedir (Ornstein \& Hunkins, 1998; Çermik, 2006). Literatürdeki bu bilgiye bağlı olarak; Çetin, İlhan ve Arslan, ilerlemecilik ve yeniden kurmacılık eğitim felsefelerini yansıtan maddeleri içeren birinci faktörü ÇEF, daimicilik ve esasicilik eğitim felsefelerini yansitan maddeleri içeren ikinci faktörü GEF olarak kısaltmışlardır (2012).

\subsection{Verilerin Analizi}

Araştırmada elde edilen veriler SPSS 17.0 paket programı kullanılarak analiz edilmiştir. Öğretmen adaylarının gerek daimicilik - esasicilik (GEF), gerekse ilerlemecilik - yeniden kurmacılık (ÇEF) eğitim felsefelerini hangi düzeyde benimsediklerini ortaya koymak için betimleyici analizler yapılmıştır. Alınan puanların bağımsız degişkenlere göre anlamlı fark gösterip göstermediğini belirlemek için bağımsız örneklem tek yönlü MANOVA ve tek yönlü ANAVO yöntemi kullanılmış, karşılaştırmalarda anlamlılık düzeyi olarak 0.05 değeri esas alınmıştır. 


\section{Bulgular}

DKAB öğretmen adaylarının, literatürde yer alan eğitim felsefelerinin hangisini, ne düzeyde tercih ettiklerinin ve söz konusu tercihlerin cinsiyet, sınıf düzeyi ve öğrenim görülen bölüm değişkenlerine göre farklılaşıp farklılaşmadığının incelendiği bu araştırmada, ortaya çıkan bulgular aşağıdaki şekildedir:

Araştırmaya 170'i kız, 118'i erkek olmak üzere toplam 288 öğrenci katılmıştır. Bunların \%43’ü DKAB Eğitimi programında, \%57'si ise ilahiyat programında öğrenim görürken; sınıf düzeyi olarak örneklem, 1. Sınıf: \% 20; 2. Sınıf: \% 24; 3. Sınıf: \% 26, 4. Sınıf: \%30 şeklinde yüzdelik dağılım göstermektedir.

Damici - esasici eğitim felsefesi (GEF) alt boyutunda ilahiyat öğrencilerinin ortalaması $(X: 3.21)$ iken DKAB öğrencilerinin ortalaması $(X: 3.28)$ düzeyindedir. $\mathrm{Bu}$ bulgulara göre; öğretmen adaylarının damici - esasici eğitim felsefesini orta düzeyde benimsedikleri söylenebilir. Alınan puanlar üzerinde yapılan MANOVA analizi sonuçları, öğretmen adaylarının GEF'i benimseme düzeylerinin cinsiyetlerine ve öğrenim gördükleri bölümlere göre anlamlı şekilde $(p>.05)$ farklılaşmadığını; ancak öğrencilerin sınıf düzeyine göre anlamlı şekilde $(p<.05)$ farklılaştığını ortaya koymaktadır. Buna göre, GEF alt boyutundan elde edilen puanların oluşturduğu doğrusal bileşen puanları öğretmen adaylarının cinsiyetlerine ve bölümlerine göre anlamlı şekilde farklılık göstermezken, sınıf düzeyi değişkenine göre farklılık göstermektedir.

İlerlemeci - yeniden kurmacı eğitim felsefesi (ÇEF) alt boyutunda ilahiyat öğrencilerinin ortalaması ( $X: 1.96)$ iken, DKAB öğrencilerinin ortalaması $(X: 2.03)$ düzeyindedir. Bu bulgulara göre; DKAB öğretmen adaylarının ilerlemeci yeniden kurmacı eğitim felsefesini düşük düzeyde benimsedikleri söylenebilir. Alınan puanlar üzerinde yapılan MANOVA analizi sonuçları, öğretmen adaylarının ÇEF'i benimseme düzeylerinin cinsiyetlerine ve öğrenim gördükleri bölümlere göre anlamlı şekilde $(p>.05)$ farklılaşmadığını; ancak öğrencilerin sınıf düzeyine göre anlamlı şekilde $(p<.05)$ farklılaştığını ortaya koymaktadır. Buna göre, ÇEF alt boyutundan elde edilen puanların oluşturduğu doğrusal bileşen puanları öğretmen adaylarının cinsiyetlerine ve bölümlerine göre anlamlı şekilde farklılık göstermezken, sınıf düzeyi değişkenine göre farklılık göstermektedir.

Hem GEF'de, hem ÇEF'de sınıf düzeyi değişkenine bağlı olarak oluşan anlamlı farkın büyüklüğünü göstermek amacıyla yapılan Eta Kare analizine ilişkin değer 0.29 olarak hesaplanmıştır. 0 - 1 aralığında değer alabilen Eta Kare analiziyle, bağımlı değişkende bağımsız değişken ile açıklanabilen varyans miktarını görmek mümkün olmaktadır. Analiz sonucunda hesaplanan Eta Kare değeri 0.01 'den küçükse bağımsız değişkenin bağımlı değişken üzerindeki etkisi küçük, 0.06 ile 0.14 arasında ise bağımsız değişkenin bağımlı değiş̧ken üzerindeki etkisi orta, .14 veya üzerinde ise bağımsız değişkenin bağımlı değişken üzerindeki etkisi büyük olduğu kabul edilmektedir (Ellis, 2010; Pallant, 2005; Akt: Çetin, İlhan ve Arslan, 2012).

Eta Kare verilerine göre; sınıf değişkenine bağlı olarak, DKAB öğretmen adaylarının ÇEF'i benimseme düzeyleri arasında görülen anlamlı farkın küçük, GEF'i benimseme düzeylerinde görülen anlamlı farkın ise büyük olduğu görülmektedir. Buna göre, sınıf değişkeninin öğretmen adaylarının daimici - esasici eğitim felsefesini benimseme düzeyleri üzerindeki etkisinin ilerlemeci - yeniden kurmacı eğitim felsefesini benimseme düzeyleri üzerindeki etkisine göre daha büyük olduğu söylenebilir. Tespit edilen anlamlı farkın, hangi bağımlı değişkenlerden kaynaklandığını belirlemek için tek yönlü ANOVA testi uygulanmış ve analiz sonucunda DKAB öğretmen adaylarının GEF ${ }^{e} i$ benimseme düzeylerinde sınıf değişkeni açısından tespit edilen anlamlı farkın dördüncü sınıf lehine iken; ÇEF'i benimseme düzeylerinde sınıf değişkeni açısından belirlenen anlamlı farkın birinci sınıf lehine olduğu anlaşılmıştır.

\section{Tartışma}

Araştırmada, DKAB öğretmen adaylarının daimici - esasici eğitim felsefesini orta düzeyde; ilerlemeci - yeniden kurmac1 eğitim felsefesini ise düşük düzeyde benimsedikleri anlaşılmıştır. Daha önce yapılan araştırmalarda farklı sonuçlara ulaşılmıştır. Üstüner (2008) tarafından yapılan araştırmada, ilköğretim müfettişlerinin ve öğretmenlerinin en fazla daimicilik eğitim felsefesini benimsedikleri tespit edilmiştir. Çetin, İlhan ve Arslan (2012) tarafından yürütülen araştırmada öğretmen adaylarının daimici - esasici eğitim felsefesini, ilerlemeci - yeniden kurmacı eğitim felsefesine göre daha yüksek düzeyde benimsedikleri tespit edilmiştir. Öğretmen adayları üzerinde yapılan başka bir araştırma (Ekiz, 2007) ile okul yöneticileri üzerinde yapilan araştırmada (Karadağ, Baloğlu ve Kaya, 2009) ise ilerlemecilik - yeniden kurmacılık eğitim felsefesinin daimicilik - esasicilik eğitim felsefesine göre daha fazla benimsendiği ortaya çıkmıştır. Yokuş (2016) tarafindan yapılan araştırma sonuçlarına göre, müzik öğretmeni adaylarının en çok tercih ettikleri eğitim felsefesinin deneyselcilik olduğu, deneyselciliği sırası ile realizm, idealizm, varoluşçuluk ve daimicilik felsefesinin izlediği belirlenmiştir. Duman (2008) tarafindan yürütülen araştırmada, Muğla Üniversitesi Eğitim Fakültesi öğrencilerinin\% 71,1 oranında deneyselcilik felsefesini benimsediği, bunu sırasıyla esasiciliğin, daimiciliğin, varoluşçuluğun ve idealizmin takip ettiği görülmüştür. Çalışkan (2013) tarafindan yürütülen araştırmada fen öğretmen adaylarının deneyselci - ilerlemeci eğitim felsefesi anlayışını benimsedikleri, öğrenme-öğretme süreçlerinde öğrencilerin yaparak-yaşayarak öğrenmelerine imkân tanıyan öğrenci merkezli yaklaşımları tercih ettikleri tespit edilmiştir. Karadağ, Baloğlu ve Kaya (2009) tarafindan yürütülen araştırmada okul yöneticilerinin, eğitim felsefesi akımlarından daimicilik ve esasicilik boyutunu düşük düzeyde, ilerlemecilik ve yeniden kurmacilık boyutunu ise yüksek düzeyde benimsedikleri saptanmıştır. Ilgaz, Bülbül ve Çuhadar (2015) tarafından yürütülen araştırmada öğretmen adaylarının varoluşçuluk ve ilerlemecilik boyutunu "kesinlikle katılıyorum"; yeniden kurmacılık boyutunu "katıliyorum"; daimicilik boyutunu "kararsızım" ve esasicilik boyutunu ise "katılmıyorum" düzeyinde benimsedikleri tespit edilmiştir.

Araştırmada, DKAB öğretmen adaylarının benimsedikleri eğitim felsefelerinin, cinsiyet değişkenine göre anlamlı şekilde farklılaşmadığı ortaya çıkmıştır. Bu bulgu, kız ve erkek öğretmen adaylarının daimici - esasici eğitim felsefesi ve ilerlemeci - yeniden kurmacı eğitim felsefesi ile ilgili 
benzer görüşlere sahip olduklarını göstermektedir. Çetin, İlhan ve Arslan (2012) tarafindan öğretmen adayları, Yokuş (2016) tarafindan müzik öğretmenleri, Doğanay ve Sarı (2003) tarafından ilköğretim öğretmenleri, Karadağ, Baloğlu ve Kaya (2009) tarafindan okul yöneticileri, Ilgaz, Bülbül ve Çuhadar (2015) tarafından farklı branşlardaki öğretmen adayları, Çağırgan Gülten ve Batdal Karaduman (2010) tarafından matematik öğretmen adayları ile yapılan araştırmalarda cinsiyetin benimsenen eğitim felsefesi üzerinde etkili bir değişken olmadığı saptanmıştır.

Araştırmada, DKAB öğretmen adaylarının benimsedikleri eğitim felsefelerinin, öğrenim görülen bölüm değişkenine göre anlamlı şekilde farklılaşmadığı ortaya çıkmıştır. Bu bulguya göre ilahiyat programında öğrenim gören öğrenciler ile din kültürü ve ahlak bilgisi programında öğrenim gören öğrenciler, benimsedikleri eğitim felsefeleri bakımından benzer eğilimi göstermektedirler. İlahiyat programından farklı olarak, DKAB Eğimi programında pedagojik formasyon derslerinin olmasına rağmen, bu farkın bir bağımsız değişken olarak öğretmen adaylarının benimsedikleri eğitim felsefeleri üzerinde anlamlı bir etki oluşturmaması dikkat çekicidir. Bu durum, din kültürü ve ahlak bilgisi branşının niteliğinin daha çok daimici - esasici eğitim felsefesiyle uyuştuğu yorumuyla açıklanabilir. Litaratürde yapılan diğer araştırmalara bakıldığında; Ilgaz, Bülbül ve Çuhadar (2015) tarafından yürütülen araştırmanın sonuçları, bu araştırmanın bulgularıyla örtüşmektedir. Ancak Duman (2008) tarafından yapılan araştırmada öğretmen adaylarının daimici eğitim felsefesini benimseme düzeylerinde anabilim dalı değişkeni açısından anlamlı fark bulunmuştur. Aynı şekilde Geçici (2000) tarafindan ilköğretim öğretmenleri ile yürütülen araştırmada da benzer sonuçlar elde edilmiş ve öğretmenlerin benimsedikleri eğitim felsefelerinin branşlarına göre farklılaştığı tespit edilmiştir. Çetin, İlhan ve Arslan (2012) tarafından yürütülen araştırmada da sosyal bilgiler öğretmen adaylarının, fen bilgisi öğretmen adaylarına göre ilerlemeci - yeniden kurmacı eğitim felsefesini daha güçlü benimsedikleri ortaya çıkmıştır. Ekiz (2007) tarafından yapılan araştırmada da matematik öğretmen adaylarının sosyal bilgiler öğretmen adaylarına göre daimicilik eğitim felsefesini daha fazla benimsedikleri sonucuna ulaşılmıştır. Aynı şekilde Üstüner (2008) tarafından yapılan araştırmada sosyal bilgiler öğretmenlerinin fen bilgisi öğretmenlerine göre, ilerlemeci eğitim felsefesini daha fazla benimsediklerini ortaya çıkmıştır. Çetin, İlhan ve Arslan (2012),bu bulgulara dayanarak sayısal ağırlıklı bölüm öğrencilerinin tamamen ya da kısmen sözel ağırlıklı bölüm öğrencilerine göre daimici esasici eğitim felsefesini daha fazla benimsedikleri sonucuna ulaşmışlardır.

Araştırmada, DKAB öğretmen adaylarının benimsedikleri eğitim felsefelerinin, sınıf düzeyi değişkenine göre anlamlı şekilde farklılaştığı ortaya çıkmıştır. $\mathrm{Bu}$ bulguya göre daimici - esasici eğitim felsefesini benimsemede, dördüncü sınıf öğrencilerinin daha güçlü eğilim gösterirken; ilerlemeci - yeniden kurmacı eğitim felsefesini benimsemede, birinci sınıf öğrencilerinin daha fazla eğilim gösterdikleri görülmüştür. $\mathrm{Bu}$ bulgu Çetin, İlhan ve Arslan (2012) yürütülen araştırmanın sonuçlarıyla örtüşmektedir. Söz konusu araştırmada, öğretmen adaylarının benimsedikleri daimici - esasici eğitim felsefelerinde 4. sınıfa devam eden öğretmen adaylarının lehine; ilerlemeci - yeniden kurmacı eğitim felsefelerinde ise 1. sınıfa devam eden öğretmen adaylarının lehine anlamlı fark bulunmuştur. Aynı şekilde Biçer, Er ve Özel (2013) tarafından yürütülen araştırma sonucunda, öğretmen adaylarının üniversitenin ilk yıllarında daimicilik felsefesini benimsediği; son yıllara gelindiğinde bu felsefeye olan inançlarında azalma olduğu belirtilmiştir. Şahin, Tunca ve Ulubey (2014) de, öğretmen adaylarının eğitim inançlarına yönelik gerçekleştirdikleri çalışmada, genel olarak öğretmen adaylarının puanlarının sınıf düzeyine göre farklılaştığını; daimici - esasici eğitim felsefesinde altsınıfların ortalamalarının üst sınıflardan daha yüksek olduğunu, ilerlemeci - yeniden kurmacıve varoluşçu eğitim felsefesinde ise üst sınıfların ortalamalarının alt sınıflardan daha yüksek olduğunu belirlemişlerdir. Bu sonuçlar, hangi branşta olursa olsun öğretmen adaylarının öğretmenliğe başlamadan önce almış oldukları eğitimin daimici - esasici eğitim felsefesini benimseme düzeylerini arttırdığını; ilerlemeci - yeniden kurmacı eğitim felsefesini benimseme düzeylerini ise azalttığını göstermektedir.

\section{Sonuç ve Öneriler}

Eğitim felsefesi, eğitimin mahiyetini tartışan, eğitim adına yapılan faaliyetleri belirleyen ve eğitim küresini oluşturan kavramları çözümleyen felsefi disiplin olarak tanımlanabilir. Eğitim felsefesinin konu edindiği, eğitimin kapsamına giren, onun içeriğini ve yönelimini belirleyen unsurların başında şüphesiz öğrenci, öğretmen, müfredat, hedefler, strateji, değer ve tutumlar gelir.

Türkiye'nin farklı üniversitelerinde öğrenim gören ilahiyat ve DKAB bölümü öğrencilerinin benimsedikleri eğitim felsefelerini tespit etmeye yönelik yürütülen bu araştırmada, öğrencilerin normatif / preskriptif özellik taşıyan daimici esasici eğitim felsefelerine orta düzeyde eğilim gösterdikleri; buna karşın ilerlemeci - yeniden kurmacı eğitim felsefelerine eğilimlerinin düşük düzeyde olduğu anlaşılmıştır. Yapılan analizler sonucunda, DKAB öğretmen adaylarının gerek söz konusu eğitim felsefelerini benimseme düzeylerinin cinsiyetlerine ve öğrenim gördükleri bölümlere göre anlamlı şekilde farklılaşmadığını; ancak öğrencilerin sınıf düzeyine göre anlamlı şekilde farklılaştığını ortaya koymaktadır. Öğrencilerin sınıf düzeyi yükseldikçe daimici - esasici eğitim felsefelerini benimseme düzeyi artarken, ilerlemeci yeniden kurmacı eğitim felsefelerini benimseme düzeyi düşmektedir.

DKAB öğretmenliği gibi pedagojik formasyon derslerinin yoğun olarak işlendiği bölüm öğrencileri ile ilahiyat gibi pedagojik formasyon derslerinin işlenmediği bölüm öğrencilerinin benimsedikleri eğitim felsefelerinin aynı olması ve benimseme düzeylerinin anlamlı şekilde farklılaşmaması, müfredatın verimliliği açısından düşündürücüdür. Diğer taraftan sınıf düzeyi yükseldikçe öğretmen adaylarının çağdaş eğitim felsefelerine olan inançlarını kaybedip, geleneksel eğitim felsefelerini daha yüksek düzeyde benimsemeleri, öğretim elemanları tarafından verilen eğitimin niteliği ile ilgili olduğunu düşündürmektedir. Konuyla ilgili gerek öğrenciler gerekse öğretim elemanları üzerinde yapılacak dar kapsamlı nitel çalışmalar, bunun sebeplerini ortaya çıkaracaktır.

\section{Kaynakça}

Arslan, A.(1998). Felsefeye Giriş. Ankara: Vadi Yayınları. 
Biçer, B., Er, H., \& Özel, A. (2013). Öğretmen Adaylarının Epistemolojik İnançları ve Benimsedikleri Eğitim Felsefeleri Arasındaki İlişki. Eğitimde Kuram ve Uygulama, 9(3), 229-242.

Cevizci, A. (2016). Eğitim Felsefesi, Say Yayınları, İstanbul.

Çağırgan Gülten, D., \& Batdal Karaduman, G. (2010). Illkögretim Matematik Öğretmen Adaylarının Ĕgitim Süreci Hakkındaki Felsefi Tercihleri ve Öğretmenlik Mesleğine Yönelik Tutumları. Eğitimde yeni Trendler ve Uygulamaları Konferansında sunulmuş sözlü bildiri, Antalya.

Çalışkan, İ. (2013). Fen Öğretmen Adaylarının EğitimFelsefesi Yaklaşımları İle Planlama Süreçleri Üzerine Bir Çalışma, Hacettepe Üniversitesi Eğitim Fakültesi Dergisi, Özel Sayı (1), 68-83.

Çetin, B., İlhan, M., \& Arslan, S. (2012). Öğretmen Adaylarının Benimsedikleri Eğitim Felsefelerinin Çeşitli Değişkenler Açısından İncelenmesi, The Journal of Academic Social Science Studies, (5)5, 149-170.

Demirel, Ö. (2003). Kuramdan Uygulamaya Eğitimde Program Geliştirme. Ankara: Pegama Yayıncılık.

Dewey, J. (1996). Demokrasi ve Eğitim. (çev. T. Yılmaz), İzmir: Ege Üniversitesi Yayınları.

Doğanay, A., \& Sarı, M. (2003). İlköğretim Öğretmenlerinin Sahip Oldukları Eğitim Felsefelerine İlişkin Algıların Değerlendirilmesi, "Öğretmenlerin Eğitim Felsefeleri". Türk Eğitim Bilimleri Dergisi, 1(3), 321-337.

Duman B., \& Ulubey, Ö. (2008). Öğretmen Adaylarının Benimsedikleri Eğitim Felsefelerinin Öğretim Teknolojilerini ve İnterneti Kullanma Düzeylerine Etkisi ile İlgili Görüşleri, Muğla Üniversitesi, Sosyal Bilimler Enstitüsü Dergisi (ILKE), 20, 95-114.

Duman, B. (2008). Öğrencilerin Benimsedikleri Eğitim Felsefeleriyle Kullanıldıkları Öğrenme Strateji Ve Öğrenme Stillerinin Karşılaştırılması, Ç.Ü. Sosyal Bilimler Enstitüsü Dergisi, 17(1), 203-224.

Ekiz, D. (2007). Öğretmen Adaylarının Eğitim Felsefesi Akımları Hakkında Görüşlerinin Farklı Programlar Açısından İncelenmesi. Ondokuz Mayıs Üniversitesi Ĕgitim Fakültesi Dergisi, 24, 1-12.

Ellis, P.D. (2010). The Essential Guide to Effect Sizes: Statistical Power, Meta-Analysis, andthe Interpretation of Research Results. Cambridge: New York: Cambridge University Press.

Ergün, M. (1996). Eğitim Felsefesi. Ankara: Ocak Yayınları.

Geçici, S. (2000). Illköğretim Öğretmenlerinin Eğitim Anlayışlarl "Uşak İli Örneği”. Yüksek Lisans Tezi. Afyon: Afyon Kocatepe Üniversitesi.

Gürsakal, N. (2001). Sosyal Bilimlerde Araştırma Yöntemleri. Bursa: Vipaş A.Ş..

Ilgaz, G., Bülbül, T., \& Çuhadar, C. (2015). Investigationof The Relationship Between Pre-Service Teachers' Educational Beliefs And Their Perceptions Of SelfEfficacy. Abant İzet Baysal Üniversitesi Ĕ̆itim Fakültesi Dergisi, 13 (1).
Karadağ, E., Baloğlu, N., \& Kaya, S. (2009). Okul Yöneticilerinin Eğitim Felsefesi Akımlarını Benimseme Düzeylerine İlişkin Ampirik Bir Çalışma. Kaygl-Uludağ Üniversitesi Felsefe Dergisi, 12, 181-200.

Karasar, N. (2006). Bilimsel Araştırma Yöntemleri. Ankara: Nobel Yayın Dağıtım.

Kop, Y. (2004). Progresivizm ve Progresivizme Eleştirel Bir Yaklaşım, Kazım Karabekir Eğitim Fakültesi Dergisi, 10(200), 270-288.

Pallant, J. (2003). Spss Survival Manual. Berkshire: Open University Press

Sönmez, V. (2011). Eğitim Felsefesi. Ankara: Anı Yayıncilik.

Şahin, S. A., Tunca, N., \& Ulubey, Ö. (2014). Öğretmen Adaylarının Eğitim İnançları İle Eleştirel Düşünme Eğilimleri Arasındaki İlişki. İlköğretim Online, 13(4), 1473-1492.

Üstüner, M. (2008). The Comparison Of The Educational Philosophies of Turkish Primary School Superintendents And Teachers. Eurasian Journal of Educational Research, 33, 177-192.

Yokuş, T. (2016). Müzik Öğretmeni Adaylarının Benimsedikleri Eğitim Felsefelerinin Çeşitli Değişkenler Açısından İncelenmesi. MSKU Eğitim Fakültesi Dergisi, (3)1, 26-36. 